\title{
KOMBINASI SISTEM PENDUKUNG KEPUTUSAN DAN SISTEM INFORMASI GEOGRAFIS DALAM PENENTUAN LOKASI INDUSTRI DI KUDUS
}

\author{
Alif Catur Murti \\ Fakultas Teknik, Program Studi Teknik Informatika \\ Universitas Muria Kudus \\ Email: alif.catur@umk.ac.id \\ Noor Yulita Dwi Setyaningsih \\ Fakultas Teknik, Program Studi Teknik Elektro \\ Universitas Muria Kudus \\ Email:noor.yulita@umk.ac.id
}

\begin{abstract}
ABSTRAK
Industri merupakan bidang yang sangat vital dibidang pembangunan, disamping sebagai pendukung utama, industri juga sangat berperan dalam peningkatan perekonomian masyarakat Indonesia pada umumnya dan wilayah daerah pada khususnya. Konsep kombinasi SPK (Sistem Pendukung Keputusan) dan SIG (Sistem Informasi Geografis) dalam penentuan lokasi industri sangat sesuai. Metode SPK yang digunakan dalam penentuan lokasi industri yang layak adalah Technique For Order Preference by Similarity to Ideal Solution (TOPSIS), kemudian hasil pengolahan data yang didapat akan divisualisasikan menggunakan (SIG). Hasil dari metode ini menunjukkan bahwa lokasi desa Gondang Manis di Kecamatan Bae adalah lokasi yang tepat untuk dijadikan lokasi industri dengan nilai preferensi 0,575 .
\end{abstract}

Kata kunci: Industri, Perekonomian, SPK, TOPSIS, SIG, Pemetaan.

\begin{abstract}
Industrial is vital part in development as main backup, industrial in common also role as developing Indonesian economic and people in the region. Combine concept of decision making system (DSS) and geographic information system (GIS) is suitable in choosing industrial location. Decision making system used in locating the suitable location is Technique For Order Preference by Similarity to Ideal Solution (TOPSIS), the result will be visualize using geographic information system. Result from these methods shows that gondang manis village in bae district is the right location for industry with preference score 0,575 .
\end{abstract}

Keywords: Industrial, economic. DSS, TOPSIS, GIS, Mapping.

\section{PENDAHULUAN}

Industri merupakan salah satu bagian yang memiliki peran penting bagi masyarakat indonesia pada umumnya dan pada khususnya adalah masyarakat wilayah Kudus. Keberadaan dari industri ini memberikan dampak yang positif bagi perekonomian masyarakat Kudus, yaitu membantu masyarakat Kudus pada khususnya untuk meningkatkan kesejahteraan di bidang perekonomian. Karena sekarang ini perekonomian di Indonesia dapat dikatakan sudah sulit, dengan banyaknya prosentase pengangguran dari usia produktif. Jika hal ini dibiarkan maka dampaknya akan ke arah kejahatan, sehingga ketahanan dan keamanan akan tidak kondusif.

Dengan beradanya industri-industri ini akan sedikit banyak membantu mengurangi pengangguran dalam masyarakat. Serta memberikan peluang atau lapangan pekerjaan bagi masyarakat sekitar untuk meningkatkan bahkan memperbaiki perekonomian. Sehingga ini merupakan PR besar dari Pemerintah Kota pada khususnya untuk dapat membuat perekonomian masyarakatnya meningkat dengan memanfaatkan keberadaan dari industri industri.

Dengan permasalahan - permasalahan tersebut, maka dibuatlah suatu sistem untuk mendeteksi keberadaan dari industri di Kota Kudus dengan memanfaatkan SPK ( Sistem Pendukung Keputusan ), sistem ini digunakan untuk menentukan solusi terbaik posisi dari industri tersebut. Karena lokasi industri ini akan berpengaruh dengan peningkatan perekonomian masyarakat di sekitar industri. Adapun variabel yang digunakan dalam pengambilan keputusan adalah luas lahan wilayah, kepadatan penduduk, kemiringan lahan dan jarak wilayah dengan pusat kota. Metode yang dipakai dalam sistem pendukung keputusan pemilihan laptop ini adalah Technique For Order Preference by Similarity to Ideal Solution (TOPSIS). TOPSIS merupakan suatu bentuk metode pendukung keputusan yang didasarkan pada konsep bahwa alternatif yang terbaik tidak hanya memiliki jarak terpendek dari 
solusi ideal positif tetapi juga memiliki jarak terpanjang dari solusi ideal negatif yang dalam hal ini akan memberikan rekomendasi pemilihan laptop yang sesuai dengan yang diharapkan. Konsep ini banyak digunakan untuk menyelesaikan masalah keputusan secara praktis. Konsepnya sederhana dan mudah dipahami, komputasinya efisien dan memiliki kemampuan untuk mengukur kinerja relatif dari alternatif-alternatif keputusan dalam bentuk matematis yang sederhana [1].

Sistem Pendukung Keputusan (SPK) memiliki kemampuan untuk memberikan solusi terbaik, tetapi untuk pengaplikasian pada data yang berhubungan dengan lapangan, SPK ini memiliki keterbatasan. Sehingga pada penelitian ini menambahkan suatu sistem agar bisa melakukan pemetaan wilayah. Adapun sistem yang digunakan adalah Sistem Informasi geografis (SIG). Kelebihan penggunaan SIG ini adalah untuk memasukkan, menyimpan, memeriksa, mengintegrasi, memanipulasi, menganalisa dan menampilkan data yang berhubungan dengan posisi permukaan bumi [2].

\subsection{Sistem Pendukung Keputusan}

Pada dasarnya sistem pendukung keputusan merupakan pengembangan lebih lanjut dari sistem informasi manajemen terkomputerisasi yang dirancang sedemikian rupa sehingga bersifat interaktif dengan pemakainya. Sifat interaktif dimaksudkan untuk memudahkan integrasi antara berbagai komponen dalam proses pengambilan keputusan seperti prosedur, kebijakan, teknik analisis, serta pengalaman dan wawasan manajerial guna membentuk suatu kerangka keputusan bersifat fleksibel [1][3].

SPK merupakan penggabungan sumber-sumber kecerdasan individu dengan kemampuan komponen untuk memperbaiki kualitas keputusan. Sistem Pendukung Keputusan juga merupakan sistem informasi berbasis komputer untuk manajemen pengambilan keputusan yang menangani masalah-masalah semi struktur [4]. Sehingga sistem pendukung keputusan bukan merupakan alat pengambilan keputusan, melainkan merupakan sistem yang membantu pengambil keputusan dengan melengkapi mereka dengan informasi dari data yang telah diolah dengan relevan dan diperlukan untuk membuat keputusan tentang suatu masalah dengan lebih cepat dan akurat. Sehingga sistem ini tidak dimaksudkan untuk menggantikan pengambilan keputusan dalam proses pembuatan keputusan [4].

SPK juga dapat merupakani sistem komputer yang mengolah data menjadi informasi untuk mengambil keputusan dari masalah semi-terstruktur yang spesifik. SPK dapat menjadi alat bantu bagi para pengambil keputusan untuk memperluas kapabilitas mereka, namun tidak untuk menggantikan penilaian mereka. SPK ditujukan untuk keputusan-keputusan yang memerlukan penilaian atau pada keputusan-keputusan yang sama sekali tidak dapat didukung oleh algoritma [5].

Sistem pendukung keputusan terdiri dari 4 komponen utama, yaitu [6]:

a. Subsistem manajemen data berfungsi sebagai memasukkan suatu database yang berisi data yang relevan untuk situasi dan dikelola oleh perangkat lunak yang disebut sistem manajemen database (DBMS). Knowledge Base berisi semua fakta, ide, hubungan dan interakasi suatu domain tertentu.

b. Subsistem manajemen basis pengetahuan bertugas untuk mendukung semua subsistem lain atau bertindak sebagai suatu komponen independen dan memberikan intelegensi untuk memperbesar pengetahuan pengambil keputusan.

c. Subsistem manajemen model Merupakan paket perangkat lunak yang memasukkan model keuangan statistik, ilmu manajemen atau model kuantitatif lainnya yang memberikan kapabilitas analitik dan manajemen perangkat lunak yang tepat.

d. Subsistem antar muka pengguna (dialog) untuk mengimplementasikan sistem kedalam program aplikasi sehingga pengguna atau pemakai dapat berkomunikasi dengan sistem yang dirancang.

\subsection{Sistem Informasi Geografis}

Definisi Sistem Informasi Geografis (SIG) selalu berkembang, bertambah, dan bervariasi. SIG juga merupakan suatu bidang kajian ilmu dan teknologi yang relatif baru, digunakan oleh berbagai bidang disiplin ilmu, dan berkembang dengan cepat. SIG dalam sistem komputer yang digunakan untuk memasukkan, menyimpan, memeriksa, mengintegrasi, memanipulasi, menganalisa dan menampilkan data yang berhubungan dengan posisi permukaan bumi [2].

GIS atau sistem informasi berbasis pemetaan dan geografi adalah sebuah alat bantu manajemen berupa informasi berbantuan komputer yang terkait dengan sistem pemetaan dan analisis terhadap segala sesuatu, serta peristiwa-peristiwa yang terjadi dimuka bumi. Teknologi GIS mengintegrasikan operasi pengolahan data berbasis database yang biasa digunakan, seperti pengambilan data berdasarkan kebutuhan serta analisis statistic dengan menggunakan visualisasi yang khas serta berbagai keuntungan yang mampu ditawarkan melalui analisis geografis melalui gambar-gambar tertentu [9][10] .

Proses Geographic Information System (GIS) biasanya dinamakan juga sebagai mapping (pemetaan). Dalam Sistem Informasi Geografis (SIG) data-data disimpan di dalam tabel (tabular data) dan spatial data (data yang memiliki karakteristik lokasi dan mewakili suatu tempat atau lokasi). GIS 
pada pemakaiannya berhubungan dengan beberapa kumpulan data (database) guna memberikan secara cepat informasi suatu tempat [11].

Sistem Informasi Geografis (SIG) dapat diaplikasikan dalam berbagai bidang seperti pendidikan, perindustrian, pariwisata, perdagangan, perhubungan, lalu lintas, pertanian, perencanaan tata guna lahan maupun infrastruktur. SIG mampu membantu pemetaan, pengolahan data, penyimpanan serta pemanggilan kembali data spasial yang ber'georeferensi'serta atributnya yang terkait berupa data non spasial [11]. Adapun uraian dari SIG berdasarkan jenis masukan, proses dan jenis keluaran dapat dilihat pada gambar 1.

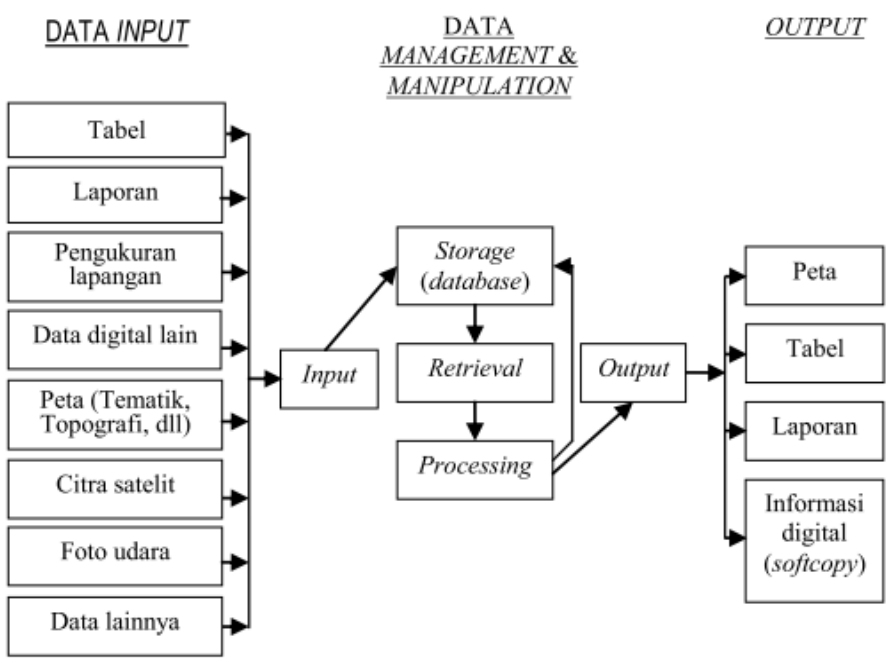

Gambar 1. Uraian Sub Sistem SIG [2]

\section{METODOLOGI PENELITIAN}

TOPSIS adalah salah satu metode yang bisa membantu proses pengambilan keputusan yang optimal untuk menyelesaikan masalah keputusan secara praktis. Hal ini disebabkan karena konsepnya sederhana dan mudah dipahami, komputasinya efisien dan memiliki kemampuan untuk mengukur kinerja relatif dari alternatif-alternatif keputusan dalam bentuk matematis sederhana [7]. Selain itu metode TOPSIS adalah salah satu metode yang digunakan untuk menyelesaikan masalah MADM. Metode TOPSIS didasarkan pada konsep dimana alternatif terpilih yang terbaik tidak hanya memiliki jarak terpendek dari solusi ideal positif, namun juga memiliki jarak terpanjang dari solusi ideal negatif [4]. Konsep ini banyak digunakan pada beberapa model MADM untuk menyelesaikan masalah keputusan secara praktis [4][8]. Secara umum, prosedur TOPSIS mengikuti langkahlangkah sebegai berikut [7][4][3]:

\subsection{Menentukan matriks keputusan yang ternormalisasi}

Matriks keputusan ternormalisasi didapat menggunakan persamaan 1.

$r i j=\frac{x i j}{\sqrt{\sum_{i=1}^{m} x^{2} x_{i j}^{j}}}$

Dengan $\mathrm{i}$ adalah $1,2,3, \ldots, \mathrm{m}$ dan $\mathrm{j}$ adalah $1,2,3, \ldots, \mathrm{n}$

$\mathrm{r}_{\mathrm{ij}}$ adalah elemen dari matriks keputusan yang ternormalisasi $\mathrm{R}$,

$\mathrm{x}_{\mathrm{ij}}$ adalah elemen dari matriks keputusan $\mathrm{X}$.

\subsection{Menghitung matriks keputusan ternormalisasi yang terbobot}

Dengan bobot $=\left(\mathrm{W}_{1}, \mathrm{~W}_{2}, \mathrm{~W}_{3}, \ldots, \mathrm{Wn}\right)$, dimana $\mathrm{Wj}$ adalah bobot dari kriteria ke-j dan $\sum_{j=1}^{n} W_{j}=1$,

maka matriks keputusan ternormalisasi yang terbobot didapat dengan menggunakan persamaan 2 .

$V_{i j}=W_{j} \quad r_{i j}$

keterangan:

$\mathrm{V}_{\mathrm{ij}}$ adalah elemen dari matriks keputusan yang ternormalisai terbobot $\mathrm{V}$,

$\mathrm{W}_{\mathrm{j}}$ adalah bobot kriteria ke-j

$\mathrm{r}_{\mathrm{ij}}$ adalah elemen dari matriks keputusan yang ternormalisasi $\mathrm{R}$. 


\subsection{Menghitung matriks solusi ideal positive dan matriks solusi ideal negative}

Solusi ideal positive dinotasikan $\mathrm{A}^{+}$dan dapat dilihat pada persamaan 3 , sedangkan solusi ideal negative dinotasikan $\mathrm{A}^{-}$dan dapat dilihat pada persamaan 4 .

$$
\begin{array}{ll}
A^{+}=\left\{\left(\max V_{i j} \mid j \in J\right),\left(\min V_{i j} \mid j \in J\right)\right. & , i=1,2,3, \ldots, m\} \\
A^{-}=\left\{\left(\max V_{i j} \mid j \in J^{\prime}\right),\left(\min V_{i j} \mid j \in J^{\prime}\right)\right. & , i=1,2,3, \ldots, m\}
\end{array}
$$

Keterangan,

$\mathrm{J}$ merupakan himpunan kriteria keuntungan (benefit criteria)\}.

J' merupakan himpunan kriteria biaya (cost criteria) \}

Vij adalah elemen dari matriks keputusan yang ternormalisasi terbobot $\mathrm{V}$

2.4 Menghitung jarak antara nilai setiap alternative dengan matriks solusi ideal positive dan matriks solusi ideal negative

a. $\mathrm{S}^{+}$adalah jarak alternative dari solusi ideal positive didefenisikan sebagai persamaan 5 .

$$
S_{i}^{+}=\sqrt{\sum_{j=1}^{m}\left(V_{i j}-V_{j}^{+}\right)^{2}}
$$

b. $\mathrm{S}^{-}$adalah jarak alternative dari solusi ideal negative didefenisikan sebagai persamaan 6 .

$$
S_{i}^{-}=\sqrt{\sum_{j=1}^{m}\left(V_{i j}-V_{j}^{-}\right)^{2}}
$$

Dengan $\mathrm{i}=1,2,3, \ldots, \mathrm{m}$

keterangan:

$\mathrm{S}_{\mathrm{i}}^{+}$adalah jarak alternative ke-I dari solusi ideal positive,

$\mathrm{Si}$ - adalah jarak alternative ke-I dari solusi ideal negative,

Vij adalah elemen dari matriks keputusan yang ternormalisasi terbobot $\mathrm{V}$,

$\mathrm{V}_{\mathrm{j}}^{+}$adalah elemen matriks solusi ideal positive,

$\mathrm{V}_{\mathrm{j}}^{-}$adalah elemen matriks solusi ideal negative.

\subsection{Menghitung nilai preferensi untuk setiap alternative}

Nilai Preferensi didapatkan dengan menggunakan persamaan 7.

$$
C_{i}^{+}=\frac{s_{i}^{-}}{\left(s_{i}^{-}+s_{i}^{+}\right)}, 0 \leq C_{i}^{+} \leq 1
$$

keterangan:

$\mathrm{C}_{\mathrm{i}}^{+}$adalah kedekatan relatif dari alternative ke-I tehadap solusi ideal positive,

$\mathrm{S}_{\mathrm{i}}^{+}$adalah jarak alternative ke-I dari solusi ideal positive,

$\mathrm{S}_{\mathrm{i}}^{-}$adalah jarak alternative ke-I dari solusi ideal negative.

\section{HASIL DAN PEMBAHASAN}

Pada bagian ini akan dibahas mengenai konsep sistem, relasi antar tabel, desain interface sistem, perhitungan metode TOPSIS, dan output sistem.

\subsection{Konsep sistem}

Konsep sistem yang dibangun melibatkan pelaku industri dan admin. Konsep sistem tersebut dapat dilihat pada gambar 2 . 


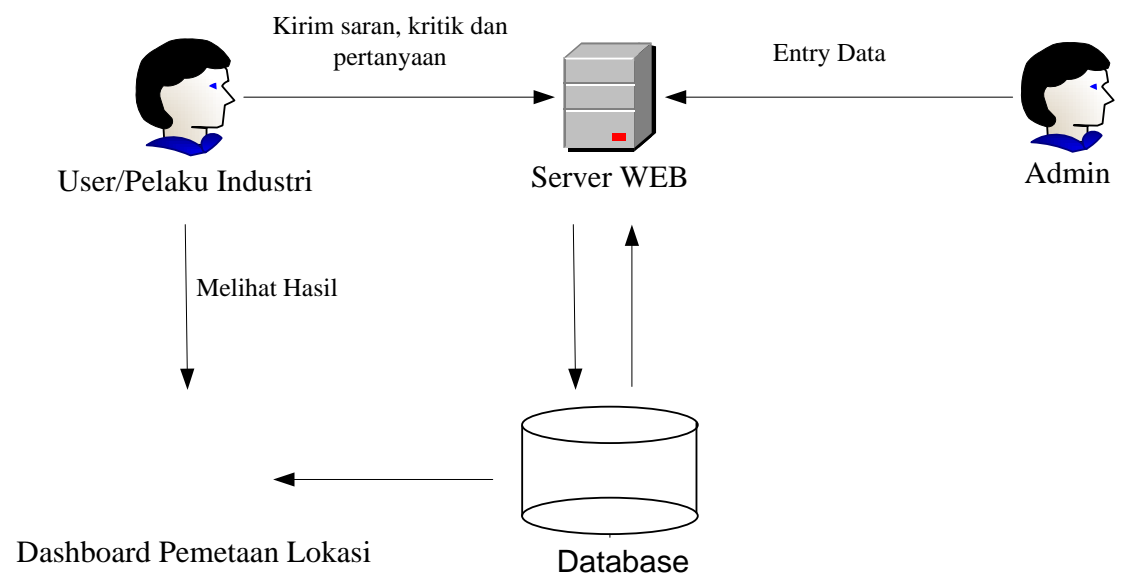

Gambar 2. Konsep Sistem

\subsection{Relasi Antar Tabel}

Sistem yang dibangun membutuhkan database sebagai tempat penyimpanan data. Hubungan antar tabel yang terbentuk pada sistem ini dapat dilihat pada gambar 3 .
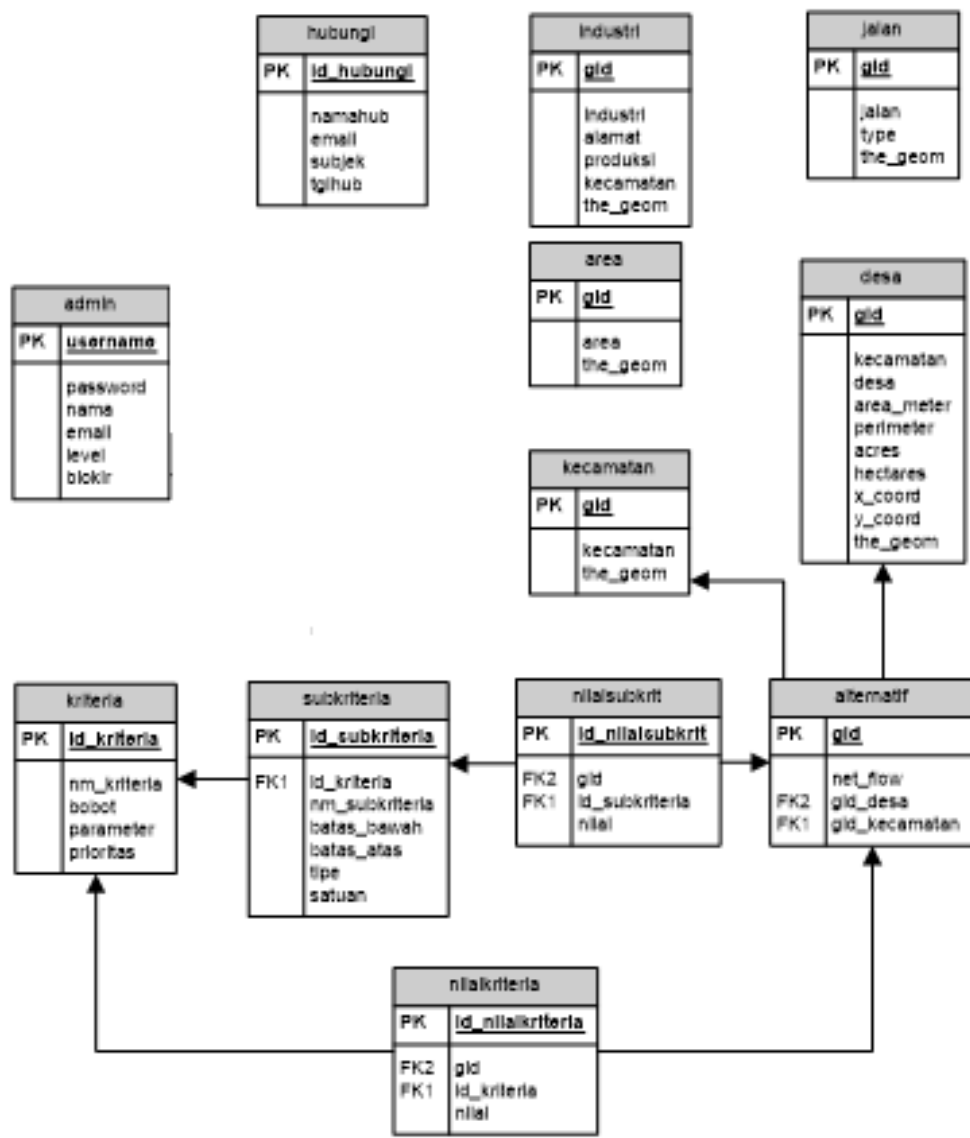

Gambar 3. Gambar Relasi Tabel

\subsection{Desain Sistem}

Antar muka sistem yang dibangun harus mudah digunakan oleh user, sehingga sistem dapat berjalan dengan efektif dan efisien. Desain sistem ini dapat dilihat pada gambar 4. 


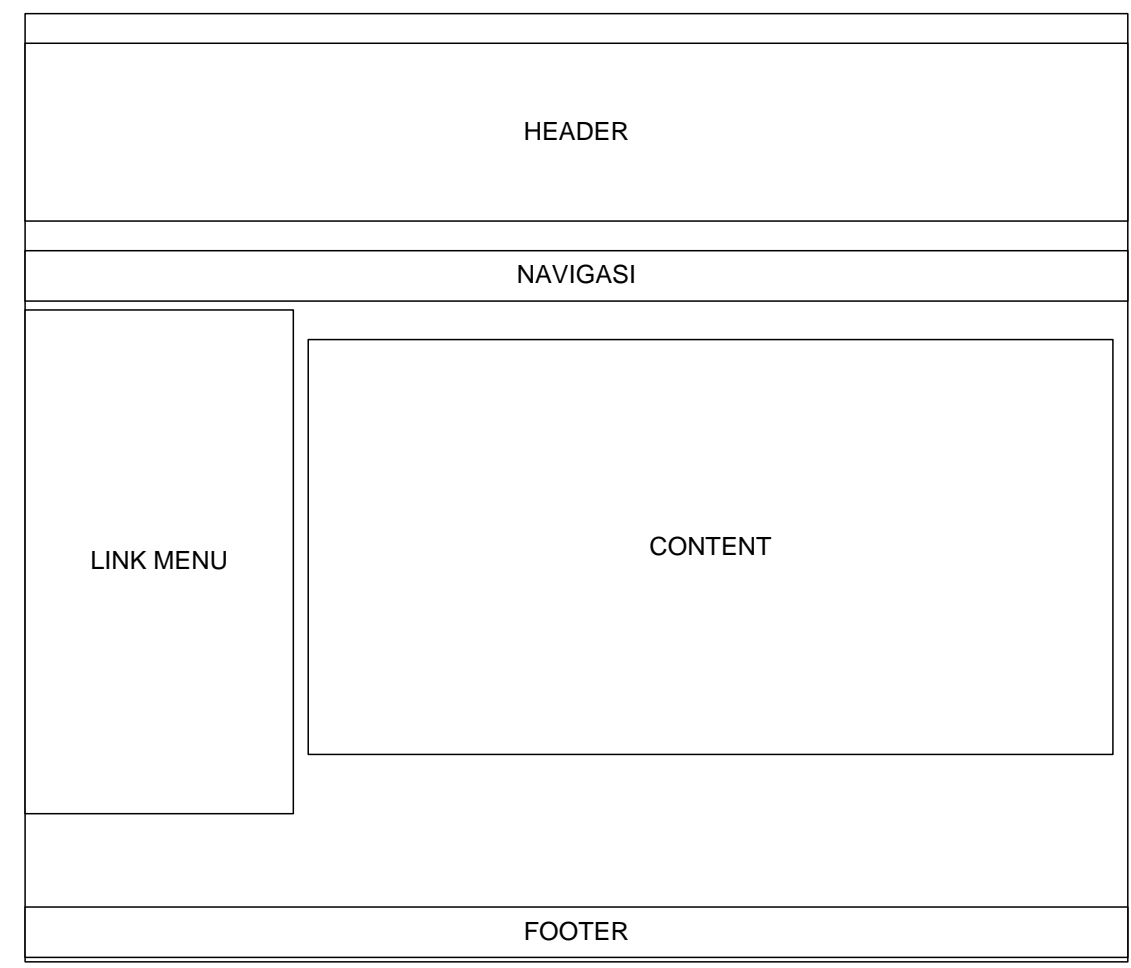

Gambar 4. Desain Halaman Utama Web

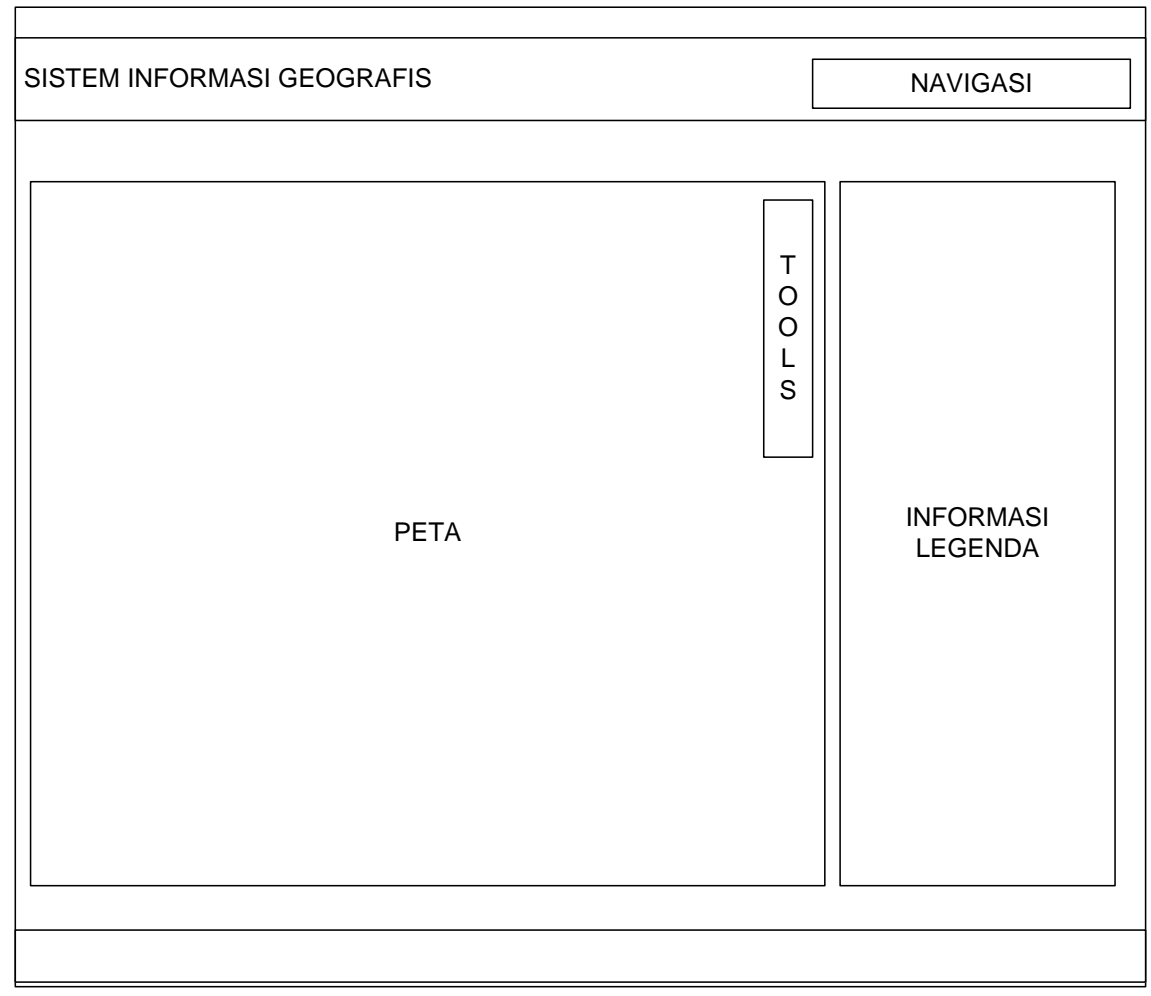

Gambar 5. Desain Halaman Web GIS

\subsection{Data Desa}

Berikut ini adalah data dari salah satu kecamatan yang ada di Kabupaten Kudus yaitu kecamatan Bae. Kriteria jarak kota, luas lahan, kemiringan lahan, dan kepadatan penduduk dari desa yang ada di Kecamatan Bae akan proses dengan menggunakan metode TOPSIS sesuai dengan langkah - langkah penyelesaian diatas. Data desa pada Kecamatan Bae dapat dilihat pada tabel 1, sedangkan pada tabel 2 merupakan data nilai kriteria desa yang telah dikonversi. 
Tabel 1. Data Desa

\begin{tabular}{llrrrr}
\hline No. & Desa & $\begin{array}{l}\text { Jarak } \\
\text { kota }\end{array}$ & $\begin{array}{l}\text { Luas } \\
\text { Lahan }\end{array}$ & Kemiringan & Kepadatan \\
\hline Kecamatan Bae & & & & & \\
1 & Peganjaran & 4.1 & 118.43 & $2-5^{\circ}$ & 3494 \\
2 & Panjang & 4 & 62.15 & $2-5^{\circ}$ & 4441 \\
3 & Purworejo & 4.7 & 59.74 & $5-15 \circ$ & 2833 \\
4 & Bacin & 3.7 & 86.85 & $2-5^{\circ}$ & 3120 \\
5 & Pedawang & 3.8 & 64.61 & $2-5^{\circ}$ & 4084 \\
6 & Ngembalrejo & 5 & 166.92 & $0-2^{\circ}$ & 3123 \\
7 & Karangbener & 7.7 & 244.52 & $2-5^{\circ}$ & 1849 \\
8 & Gondangmanis & 7.4 & 346.32 & $5-15 \circ$ & 2707 \\
\hline
\end{tabular}

Tabel 2. Data Desa Di Kecamatan Bae

\begin{tabular}{llrrrr}
\hline No. & Desa & $\begin{array}{l}\text { Jarak } \\
\text { kota }\end{array}$ & Luas Lahan & Kemiringan & Kepadatan \\
\hline Kecamatan Bae & & & & & \\
\hline 1 & Peganjaran & 4.1 & 118.43 & 80 & 3494 \\
2 & Panjang & 4 & 62.15 & 80 & 4441 \\
3 & Purworejo & 4.7 & 59.74 & 60 & 2833 \\
4 & Bacin & 3.7 & 86.85 & 80 & 3120 \\
5 & Pedawang & 3.8 & 64.61 & 80 & 4084 \\
6 & Ngembalrejo & 5 & 166.92 & 100 & 3123 \\
7 & Karangbener & 7.7 & 244.52 & 80 & 1849 \\
8 & Gondangmanis & 7.4 & 346.32 & 60 & 2707 \\
Nilai Max dari keseluruhan & 13.8 & 606.5 & 100 & 19258 \\
kecamatan & & & & & \\
Nilai Min dari keseluruhan & 0.3 & 10.36 & 40 & 906 \\
kecamatan & & & & & \\
\hline
\end{tabular}

Proses inverse score hanya dilakukan pada kriteria jarak kota. Hal ini disebabkan karena semakin dekat jarak daerah ke kota, semakin memiliki nilai yang besar. Pada tabel 3 dapat dilihat perubahan inverse score pada kriteria jarak kota.

Tabel 3. Tabel Inverse Score Jarak Kota

\begin{tabular}{llrrrr}
\hline Inverse Score & Desa & $\begin{array}{l}\text { Jarak } \\
\text { kota }\end{array}$ & $\begin{array}{l}\text { Luas } \\
\text { Lahan }\end{array}$ & Kemiringan & Kepadatan \\
\hline 1 & Peganjaran & 10 & 118.43 & 80 & 3494 \\
2 & Panjang & 10.1 & 62.15 & 80 & 4441 \\
3 & Purworejo & 9.4 & 59.74 & 60 & 2833 \\
4 & Bacin & 10.4 & 86.85 & 80 & 3120 \\
5 & Pedawang & 10.3 & 64.61 & 80 & 4084 \\
6 & Ngembalrejo & 9.1 & 166.92 & 100 & 3123 \\
7 & Karangbener & 6.4 & 244.52 & 80 & 1849 \\
8 & Gondangmanis & 6.7 & 346.32 & 60 & 2707 \\
\hline
\end{tabular}

Sebelum didapatkan nilai preferensi untuk masing - masing alternative, didapatkan terlebih dahulu nilai solusi ideal positive dan nilai ideal negative. Nilai solusi ideal positive dapat dilihat pada tabel 4 dan solusi ideal negative dapat dilihat pada tabel 5. 
Tabel 4. Tabel Jarak Alternative Dari Solusi Ideal Positive

\begin{tabular}{llrrrrrr}
\hline \multirow{2}{*}{ NO } & Desa & $\begin{array}{l}\text { Jarak } \\
\text { kota }\end{array}$ & $\begin{array}{l}\text { Luas } \\
\text { Lahan }\end{array}$ & Kemiringan & Kepadatan & \multicolumn{1}{c}{$\mathrm{S}_{\mathrm{i}}^{+}$} \\
\hline 1 & Peganjaran & -0.40 & -12.21 & -4.49 & -3.45 & 13.46 \\
2 & Panjang & -0.30 & -15.22 & -4.49 & 0.00 & 15.87 \\
3 & Purworejo & -1.00 & -15.35 & -8.98 & -5.87 & 18.75 \\
4 & Bacin & 0.00 & -13.90 & -4.49 & -4.82 & 15.38 \\
5 & Pedawang & -0.10 & -15.09 & -4.49 & -1.30 & 15.80 \\
6 & Ngembalrejo & -1.29 & -9.61 & 0.00 & -4.81 & 10.82 \\
7 & Karangbener & -3.98 & -5.45 & -4.49 & -9.46 & 12.46 \\
8 & Gondangmanis & -3.68 & 0.00 & -8.98 & -6.33 & 11.59 \\
\hline
\end{tabular}

Tabel 5. Tabel Jarak Alternative Dari Solusi Ideal Negative

\begin{tabular}{llrrrrr}
\hline \multirow{2}{*}{ NO } & Desa & $\begin{array}{l}\text { Jarak } \\
\text { kota }\end{array}$ & $\begin{array}{l}\text { Luas } \\
\text { Lahan }\end{array}$ & Kemiringan & Kepadatan & \multicolumn{2}{c}{$\mathrm{S}_{\mathrm{i}}^{-}$} \\
\hline 1 & Peganjaran & 3.58 & 3.14 & 4.49 & 6.00 & 8.88 \\
2 & Panjang & 3.68 & 0.13 & 4.49 & 9.46 & 11.10 \\
3 & Purworejo & 2.99 & 0.00 & 0.00 & 3.59 & 4.67 \\
4 & Bacin & 3.98 & 1.45 & 4.49 & 4.64 & 7.72 \\
5 & Pedawang & 3.88 & 0.26 & 4.49 & 8.15 & 10.09 \\
6 & Ngembalrejo & 2.69 & 5.74 & 8.98 & 4.65 & 11.93 \\
7 & Karangbener & 0.00 & 9.90 & 4.49 & 0.00 & 10.87 \\
8 & Gondangmanis & 0.30 & 15.35 & 0.00 & 3.13 & 15.67 \\
\hline
\end{tabular}

Hasil akhir dari perhitungan metode TOPSIS adalah didapatkannya nilai preferensi untuk masing masing alternatif. Semakin besar nilai preferensi yang dimiliki suatu daerah maka daerah tersebut yang menjadi prioritas utama. Pada tabel 6 dapat dilihati nilai preferensi dan rangking alternative. Berdasarkan tabel 6 desa yang memiliki prioritas utama adalah Gondang Manis dengan nilai preferensi 0.575 . Nilai preferensi yang dihasilkan dipengaruhi oleh jumlah kriteria yang digunakan serta bobot kepentingan dari masing - masing kriteria.

Tabel 6. Tabel Nilai Preferensi Altenative

\begin{tabular}{llcc}
\hline NO & Desa & Nilai Preferensi & $\begin{array}{c}\text { Rangking } \\
\text { Alternative }\end{array}$ \\
\hline 1 & Peganjaran & 0.398 & 5 \\
2 & Panjang & 0.411 & 4 \\
3 & Purworejo & 0.199 & 8 \\
4 & Bacin & 0.334 & 7 \\
5 & Pedawang & 0.390 & 6 \\
6 & Ngembalrejo & 0.524 & 2 \\
7 & Karangbener & 0.466 & 3 \\
8 & Gondangmanis & 0.575 & 1 \\
\hline
\end{tabular}

\subsection{Output Sistem}

Setelah didapatkan nilai preferensi dari perhitungan menggunakan TOPSIS, maka sistem akan secara otomatis memvisualisasikan daerah dengan menggunakan gradasi warna merah. Warna merah pekat menunjukkan bahwa lokasi tersebut adalah daerah yang memiliki prioritas utama atau memiliki nilai preferensi yang paling tinggi. Output sistem dapat dilihat pada gambar 6 . 


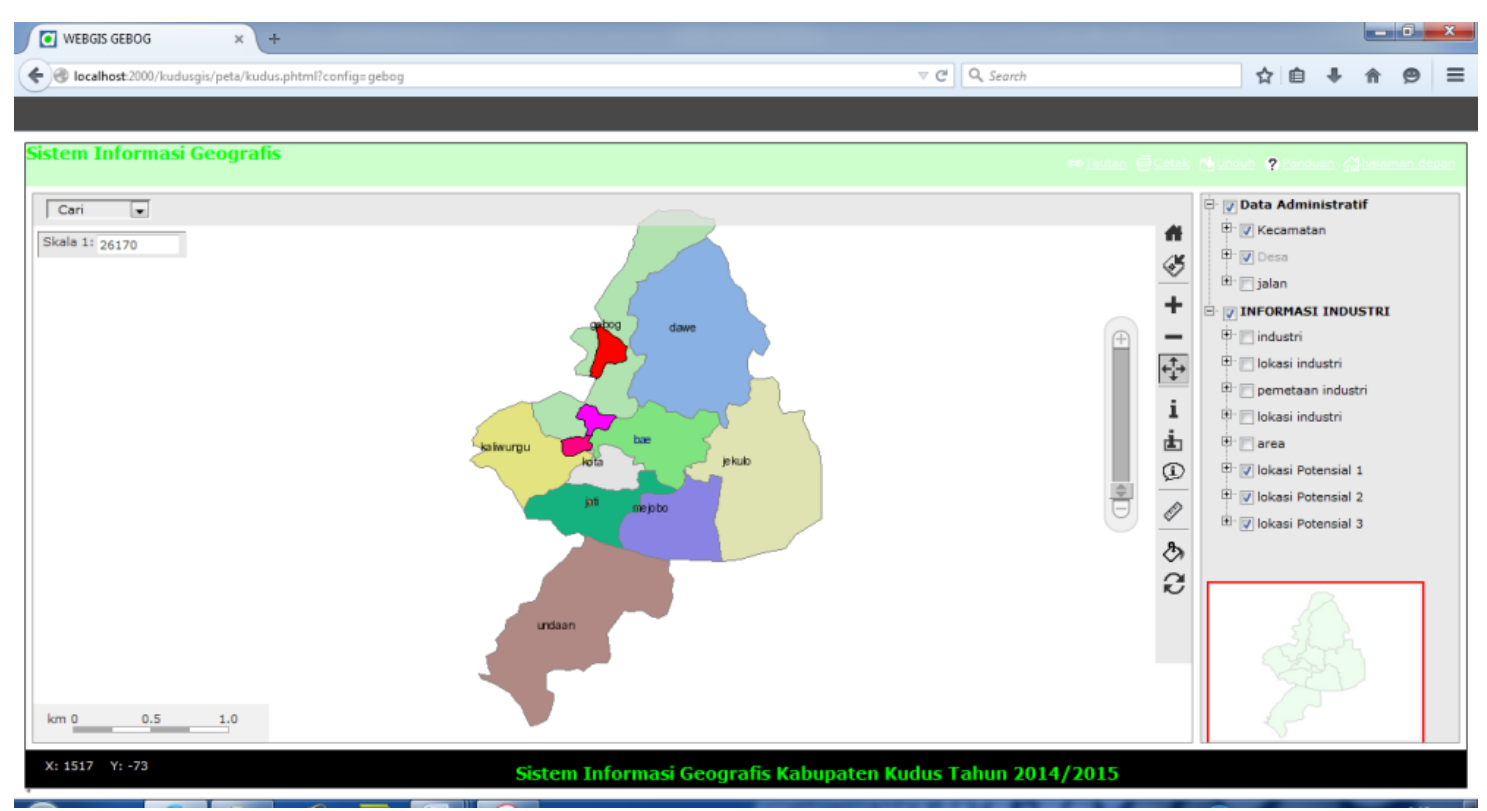

Gambar 6. Output Sistem

\section{KESIMPULAN}

Berdasarkan hasil yang didapat, menunjukkan bahwa Desa Gondang Manis di Kecamatan Bae merupakan daerah yang layak dijadikan lokasi Industri dengan nilai preferensi 0,575. Hasil tersebut kemudian divisualisasikan dengan menggunakan Sistem Informasi Geografis, sehingga dengan mudah dapat diketahui bahwa lokasi dengan warna merah pekat merupakan daerah yang layak industri.

\section{DAFTAR PUSTAKA}

[1] D. L. Kurniasih, "Sistem Pendukung Keputusan Pemilihan Laptop dengan Metode Topsis," Pelita Inform. budi Darma, vol. III, no. April, pp. 6-13, 2013.

[2] V. I. R. T. Edy Harseno, “Aplikasi Sistem Informasi Geografis Dalam Pemetaan Batas Administrasi, Tanah, geologi, Penggunaan Lahan, Lereng, Daerah Istimewa Yogyakarta dan Daerah Aliran Sungai di Jawa Tengah menggunakan Software Arcview GIS," Majalah Imliah UKRIM Edisi 1/th XII/2007, pp. 63-80, 2007.

[3] N. G. Perdana and T. Widodo, "Sistem Pendukung Keputusan Pemberian Beasiswa Kepada Peserta Didik Baru Menggunakan Metode TOPSIS,” in Semantik 2013, 2013, vol. 2013, no. November, pp. 265-272.

[4] A. F. Siddiq and U. W. Bandung, "Sistem Pendukung Keputusan Menggunakan Metode Technique for Order by Similarity to Ideal Solution (TOPSIS)," J. Sist. Inf., vol. 4, no. 1, pp. 398-412, 2012.

[5] M. Asfi and R. P. Sari, "Sistem Penunjang Keputusan Seleksi Mahasiswa Berprestasi Menggunakan Metode AHP ( Studi Kasus : STMIK CIC Cirebon ),” J. Inform., vol. 6, no. 202, pp. 131-144, 2010.

[6] S. W. Nila Susanti, "Sistem Pendukung Keputusan Penentuan Kualitas Kayu untuk Kerajinan MEUBEL,” J. Sarj. Tek. Inform., vol. 1, no. 2338-5197, pp. 327-337, 2013.

[7] A. N. Fitriana, "Sistem Pendukung Keputusan Untuk Menentukan Prestasi Akademik Siswa dengan Metode TOPSIS," Citec J., vol. 2, no. 2, pp. 153-164, 2015.

[8] R. J. Amin Karami, "Utilization of Multi Attribute Decision Making Techniques to Integrate Automatic and Manual Ranking of Options," J. Inf. Sci. Eng., vol. 534, pp. 519-534, 2014.

[9] H. F. Qoriani, "Ssitem informasi Geografis untuk Mengetahui Tingkat Pencemaran Limbah Pabrik di Kabupaten Sioarjo," J. LINK, vol. 17, no. 2, pp. 1-8, 2012.

[10] I. F. Nitya, S. Syaukat, R. P. Tambunan, and T. E. B. Soesilo, "Penggunaan Sistem Informasi Geografi Efektif Memprediksi Potensi Demam Berdarah di Kelurahan Endemik," Makara Kesehat., vol. 15 , no. 1 , pp. $21-30,2011$. 
[11] A. Sistem, I. Geografis, and I. I. Mildawani, "Aplikasi Sistem Informasi Geografis (SIG) Dalam Analisis Pemanfaatan dan Pengelolaan Ruang Terbuka Hijau Kota (RTHK) Studi Kasus: Kota Depok." 